\title{
Protective Effect of Ca- Folinate and Ginseng in Male Rats Treated with Methotrexate
}

\author{
Fawkyeia El Hodairy \\ National Organization for Drug Control and Research NODCAR Physiology Department
}

\begin{abstract}
The objective of this study was to assess the prevalence of neuron and hepatotoxicity of Methotrexate $(M T X)$ and prophylactic response to Ca-Folinate $(\mathrm{Ca}-\mathrm{F})$ and Ginseng $(G)$. Forty two of male albino rat were divided to seven groups six rats for each. $1^{\text {st }}$ control group received $1 \mathrm{ml}$ saline i.p daily for 4weeks $(C), 2^{\text {nd }}$ group treated with Ca-F (5 mg / $\mathrm{kg}$ b.wt i.p.) for 4 weeks. $3^{\text {rd }}$ group treated with $\mathrm{G}$ ( $25 \mathrm{mg} / \mathrm{kg}$ b.wt orally) for 4 weeks. $4^{\text {th }}$ group treated with MTX $(0.45 \mathrm{mg} / \mathrm{kg}$ b.wt i.p. $)$ for 4 weeks. $5^{\text {th }}$ group treated with MTX $+\mathrm{Ca}-\mathrm{F}(0.45$ $\mathrm{mg} / \mathrm{kg}$ and $5 \mathrm{mg} / \mathrm{kg}$ i.p. $)$ for 4 weeks, respectively. $6^{\text {th }}$ group treated with $M T X+G(0.45 \mathrm{mg} / \mathrm{kg}$ and $25 \mathrm{mg} / \mathrm{kg}$ i.p.) for 4 weeks, respectively. $7^{\text {th }}$ group treated with MTX $+C a-F+G(0.45 \mathrm{mg} / \mathrm{kg}, 5 \mathrm{mg} / \mathrm{kg}$ and $25 \mathrm{mg} / \mathrm{kg}$ i.p) for 4 weeks, respectively. In this study, aspartic acid (ASP), glutamic acid (GLU), ALT, AST, $\gamma$-GT, MDA, GSSG and NO were increase $(P<0.05)$ in MTX group comparing with control group in rat brain. Glycine $(G L Y), \gamma$ amino butyric acid (GABA), Norepinephrine (NE), Dopamine (DA), serotonin (5TH) and GSH were decrease $(P<0.05)$ in MTX group comparing with control group in rat brain. All these parameters were improved with $G, F$ and there combination comparing with MTX group. Histopathological examination showed ameliorates effect for all treatments against MTX pathogenesety. It could be concluded that $F$ and $G$ influences and regeneration of neurons amino acids and catecholamine's activity and decrease liver enzymes and oxidative stress markers.
\end{abstract}

Keywords: Methotrexate, CA-folinate, Ginseng, neurotransmitters and Amino acids.

\section{Introduction}

Methotrexate (MTX) is an anti-metabolite widely used in the treatment of neoplastic disorders, Rheumatoid arthritis and psoriasis. The basis for its therapeutic efficacy is the inhibition of dihydrofolate reducates (DHFR), which a key enzyme in the folic acid (FA) metabolism. MTX may induce severe toxicity during treatment of both human and experimental animals (Li et al., 1956).

Folinic acid (FNA) is the beneficial effect might include reduced risk of vascular disease, anemia, neuropathy and sub-acute combined degeneration of the spinal cord. Folate may aggravate epilepsy, inflammatory arthritis, familial hyper lipidemeia, hypercholesterolemia, hyper homocysteinemia and diabetes mellitus. FNA reduces both toxicity and side effects of MTX in human compromising the idiopathic arthritis (Kelly, 1998).

Ginseng extract is the dried roots of the Korean Panax ginseng which contain a combination of pharmacological important ingredients including ginsenosides (saponin glycosides), oil, phytosterols, carbohydrates, sugars, amino acids, peptides, vitamins, minerals and certain enzymes (Xun and Zhou, 2003). Ginseng exerts has a wide range of pharmacological activities on oral administration. It improves the psychomotor functions with evident anti-fatigue and anti-stress properties. In addition, the combined components of ginseng extract act directly on body cells and promote DNA and protein synthesis and increase in the specific activities of enzymes associated with cellular metabolism (Saito et al., 1977).

The aim of this work to study how to decrease the side effect of MTX (toxicity) which used in treatment of cancer and rheumatoid arthritis by adding CA-folinic acid (Ca-F) and ginseng to ameliorate the neurotoxicity and hepatotoxicity of MTX in brain and liver in rats.

\section{Chemicals}

\section{Materials and Methods}

Aspartic acid, GLU, GLY, GABA, NE, DA, 5HT, MDA, GSH, GSSG and NO standard for High Performance Liquid Chromatography (HPLC) was purchased from SIGMA Company and MTX was purchased from Glacso Company. AST, ALT and $\gamma$ GT were determined by spectrophtometric method by bio diagnostic kit which purchased from Bio-diagnostic Company.

\section{Animals and Experimental Design:}

The present study was carried out using adult male albino rats obtained from the animal house of National organization of Drug Control and Research (NODCAR) their average weights ranged from 180-200 g. 
The animals were housed in standard conditions, animals were allowed to access standard diet and water ad libtum. Animals were cared in accordance with standard guidelines (Olfert et al., 1993).

Animals were divided into 7 groups namely

1. Control group, animal were received $1 \mathrm{ml}$ saline i.p daily for 4 weeks.

2. Ca-folinate $(\mathrm{Ca}-\mathrm{F})$ treated group animals were received $\mathrm{Ca}-\mathrm{F}$ in a dose $(5 \mathrm{mg} / \mathrm{kg})$ b.wt i.p. for 4 weeks.

3. Ginseng $(\mathrm{G})$ in a dose $(25 \mathrm{mg} / \mathrm{kg})$ orally for 4 weeks.

4. MTX -treated group animals were received MTX in a dose $(0.45 \mathrm{mg} / \mathrm{kg})$ b.wt i.p. for 4weeks.

5. MTX+ Ca-F group, animals were received MTX in a dose $0.45 \mathrm{mg} / \mathrm{kg}$ b.wt i.p. + Ca-folinate in a dose $(5 \mathrm{mg} / \mathrm{kg})$ b.wt i.p. for 4 weeks.

6. MTX + G group, animals were received MTX in a dose $(0.45 \mathrm{mg} / \mathrm{kg})$ b.wt i.p. $+\mathrm{Gn}$ in a dose $(25 \mathrm{mg} / \mathrm{kg})$ orally for 4weeks.

7. MTX $+\mathrm{Ca}-\mathrm{F}+\mathrm{G}$ group, animals were received MTX in a dose $(0.45 \mathrm{mg} / \mathrm{kg})$ b.wt i.p. $+\mathrm{Ca}-\mathrm{F}$ in a dose $(5 \mathrm{mg} / \mathrm{kg})$ b.wt i.p. for 4 weeks $+\mathrm{G}$ in a dose $(25 \mathrm{mg} / \mathrm{kg})$ orally for 4 weeks.

Serum, Brain and Liver were taken after 4 weeks. Brain was homogenate in $70 \%$ methanol then centrifuge at 5000 r.p.m. Supernatant was taken for determination of neurotransmitter NE, DA, 5HT and amino acids ASP, GIY, GLU and GABA by HPLC. Liver oxidative stress marker (MDA, GSH, GSSG and NO) were determined by HPLC and histopathological examination were taken from rats in different groups and fixed in $10 \%$ formal saline for twenty four hours.

\section{Determination of Brain Amino Acids:}

Each brain tissue was weighed and homogenized in $75 \%$ aqueous HPLC grade methanol $(10 \% \mathrm{w} / \mathrm{v})$ (Arafa et al., 2010). The homogenate was spun at 4000 r.p.m. for $10 \mathrm{~min}$. and the supernatant was divided into two halves; the first was dried using vacuum (70 Millipore) at room temperature and used for amino acids ASP, GLU, GLY and GABA (gammaamino- butyric acid, whereas the second half was used for monoamine determination. Brain amino acids were detected by High Performance Liquid Chromatography (HPLC) using the precolumn PITC derivatization technique according to the method of Heinrikson and Meredith (1984).

\section{Determination of the brain monoamines concentrations by HPLC method}

The HPLC system Agilent 1200 series USA consisted of quaternary pump; a column oven, Rheodine injector and $20 \mu \mathrm{l}$ loop, UV variable wavelength detector. The report and chromatogram taken from chemstation program. The sample was immediately extracted from the trace elements and lipids by the use of solid phase extraction chromabond column NH2 phase cat. No.730031. the sample was then injected directly into an AQUA column $15054.6 \mathrm{~mm} 5 \mu \mathrm{C} 18$, purchased from phenomenex, USA under the following conditions: mobile phase $20 \mathrm{mM}$ potassium phosphate, $\mathrm{pH} 2.5$, flow rate $1.5 \mathrm{ml} / \mathrm{min}$, UV $190 \mathrm{~nm}$. The resulting chromatogram identified each monoamine position and concentration from the sample as compared to that of the standard, and finally, the determination of the content of each monoamine as $\mu \mathrm{g} /$ gram brain tissue (Pagel et al., 2000).

Assessment of Liver Function: Serum was used for the determination alanine aminotransferase (ALT), aspartate aminotransferase (AST) and $\gamma$-GT activities by spectrophotometric method using Bio-diagnositc from Bio-diagnositc Company

\section{Evaluation of Liver Biomarkers of Oxidative Stress: \\ Determination of MDA by HPLC \\ Preparation of the standard solution}

MDA standard was prepared by dissolving $25 \mu \mathrm{L}$ 1,1,3,3 tetraethoxypropane (TEP) in $100 \mathrm{ml}$ of water to give a $1 \mathrm{mM}$ stock solution. Working standard was prepared by hydrolysis of $1 \mathrm{ml}$ TEP stock solution in 50 $\mathrm{ml} 1 \%$ sulfuric acid and incubation for $2 \mathrm{~h}$ at room temperature. The resulting MDA standard of $20 \mathrm{nmol} / \mathrm{ml}$ was further diluted with $1 \%$ sulfuric acid to yield the final concentration of $1.25 \mathrm{nmol} / \mathrm{ml}$ to get the standard for the estimation of total MDA (Karatepe, 2004).

\section{HPLC Analysis}

The samples were analyzed on an Agilent HP 1100 series HPLC apparatus (USA). The analytical column Supelcosil C18 (5 $\mu \mathrm{m}$ particle and 80 Ao pore size) $(250$ x 4.6 ID). Mobile phase consists of $30 \mathrm{mmol}$ $\mathrm{KH}_{2} \mathrm{PO}_{4}$ and methanol $(65 \%-35 \%, \mathrm{H} 3 \mathrm{PO} 4$ by $\mathrm{pH} 4)$, and the mobile phase at a $1.5 \mathrm{ml} / \mathrm{min}$ flow rate, wavelength $250 \mathrm{~nm}$. According to the method of Karalas et al., 2002.

Determination of GSH and GSSG by HPLC: The thiols compounds of oxidized and reduced glutathione were detected by HPLC using the method of Jayatilleke and Shaw (1993). Glutathione (oxidized and reduced) 
reference standard purchased from Sigma Chemical Co. Dissolved in $75 \%$ methanol in stock $1 \mathrm{mg} / \mathrm{ml}$ and diluted before application to HPLC.

The HPLC system of Agilent consisted of quaternary pump, a column oven, Rheodine injector and $20 \mu 1$ loop, UV variable wavelength detector. The report and chromatogram taken from Chemstation program purchased from Agilent. Synerji RP Max column 3.9 at wavelength $210 \mathrm{~nm}$ with flow rate $2 \mathrm{ml} / \mathrm{min}$ was used. Pot. Phosphate buffer - acetonitrile at PH 2.7 was used as an isocratic mobile phase.

Determination of nitrites and nitrates by HPLC: Nitrites and nitrate was determined according to the method of Papadoyannis et al., (1999) by HPLC

Preparation of the standard solution: Sodium nitrite and sodium nitrate used for the reference standard preparation with stock concentration $1 \mathrm{mg} / \mathrm{ml}$. A standard mixture of nitrite and nitrate was used to determine the retention times and separation of the peaks. Nitrite and nitrate concentrations were equal in the mixture solution.

HPLC Analysis: The samples were analyzed on an Agilent HP 1200 series HPLC apparatus (USA). The analytical column was anion exchange PRP-X100 Hamilton, $150 \times 4.1 \mathrm{~mm}, 10 \mu \mathrm{m}$. The mobile phase was a mixture of $0.1 \mathrm{M} \mathrm{NaCl}$ - methanol, at a volume ratio $45: 55$. The flow rate of $2 \mathrm{~mL} / \mathrm{min}$, wavelength adjusted to $230 \mathrm{~nm}$.

\section{Histopathological Examination:}

Autopsy samples were taken from the liver of rats in different groups and fixed in $10 \%$ formol saline for twenty four hours. Washing was done in tap water then serial dilutions of alcohol (methyl, ethyl and absolute ethyl) were used for dehydration. Specimens were cleared in xylene and embedded in paraffin at 56 degree in hot air oven for twenty four hours. Paraffin bees wax tissue blocks were prepared for sectioning at 4 microns thickness by slidge microtome. The obtained tissue sections were collected on glass slides, deparaffinized, and stained by hematoxylin \&eosin stain for examination through the light electric microscope (Bancroft et al., 1996).

\section{Statistical Analysis:}

Statistical package for social science SPSS (version 18) statistical program (SPSS Inc., Chicago, IL, USA) was used to carry out a one-way analysis of variance (ANOVA) on our data. When significant differences by ANOVA were detected, analysis of differences between the means of the treated and control groups were performed by using Duncan's test.

\section{Results}

Table (1): Effect of Ca-folinate, ginseng and their combined treatments on serum levels of ASP, GLU, GLY and GABA ( $\mu \mathrm{g} / \mathrm{gm}$ tissue) in rats treated with Methotrexate (MTX).

\begin{tabular}{|c|c|c|c|c|}
\hline \multirow[t]{2}{*}{ Groups } & \multicolumn{4}{|c|}{ Parameters (Brain amino acids) } \\
\hline & ASP & GLU & GLY & GABA \\
\hline $\mathbf{C}$ & $2.15 \pm 0.168$ & $2.319 \pm 0.129$ & $2.699 \pm 0.26$ & $2.299 \pm 0.215$ \\
\hline Ca-F & $3.95 \pm 0.314 a b$ & $2.759 \pm 0.187 \mathrm{ab}$ & $2.94 \pm 0.269 \mathrm{~b}$ & $2.779 \pm 0.253 \mathrm{ab}$ \\
\hline G & $3.93 \pm 0.264 \mathrm{ab}$ & $2.807 \pm 0.264 \mathrm{ab}$ & $2.747 \pm 0.202 b$ & $2.802 \pm 0.225 \mathrm{ab}$ \\
\hline MTX & $6.945 \pm 0.474 a$ & $4.831 \pm 0.481 \mathrm{a}$ & $0.706 \pm 0.053 \mathrm{a}$ & $1.125 \pm 0.077 \mathrm{a}$ \\
\hline MTX + Ca-F & $4.312 \pm 0.332 \mathrm{a}$ & $3.239 \pm 0.26 \mathrm{ab}$ & $1.191 \pm 0.08 \mathrm{ab}$ & $1.818 \pm 0.181 \mathrm{ab}$ \\
\hline MTX +G & $4.026 \pm 0.36 a$ & $2.463 \pm 0.206 \mathrm{ab}$ & $1.914 \pm 0.136 \mathrm{ab}$ & $1.33 \pm 0.133 a$ \\
\hline $\mathrm{MTX}+\mathrm{Ca}-\mathrm{F}+\mathrm{G}$ & $2.604 \pm 0.174 b$ & $2.528 \pm 0.207 \mathrm{ab}$ & $1.526 \pm 0.127 \mathrm{ab}$ & $1.83 \pm 0.128 \mathrm{ab}$ \\
\hline
\end{tabular}

- a significant from control group with one way ANOVA at $\mathrm{P}<0.05$.

- $\quad$ b significant from $\mathrm{M}$ group with one way ANOVA at $\mathrm{P}<0.05$.

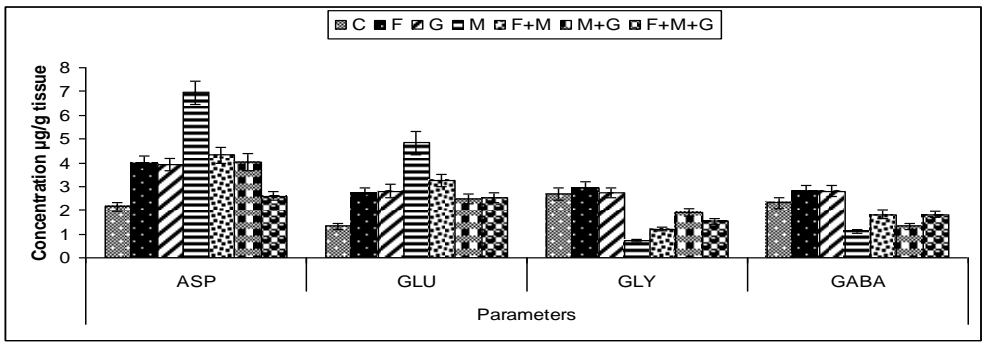

Figure (1): Effect of Ca-folinate, ginseng and their combined treatments on serum levels of ASP, GLU, GLY and GABA ( $\mu \mathrm{g} / \mathrm{gm}$ tissue) in rats treated with Methotrexate (MTX). 
There were an increase in ASP and GLU in groups treated with MTX p $(<0.05)$ in comparing with control. While there were a decrease in GLY and GABA in groups treated with MTX comparing with control. Also there was a decrease in ASP and GLU in groups treated with Ca-F + MTX, Gn + MTX and with Ca-F $+\mathrm{Gn}+\mathrm{MTX}$ in comparing with MTX. Also there were an increase in GLY and GABA in groups treated with Ca-F +MTX, G n +MTX and with Ca-folinate + MTX+G in comparing with MTX. Table (1) and fig (1).

Table (2): Effect of Ca-folinate, Ginseng and their combined treatments on monoamines levels in brain of rats treated with Methotrexate (MTX).

\begin{tabular}{|l|l|l|l|}
\hline \multirow{2}{*}{ Groups } & \multicolumn{3}{|l|}{ Parameters (Brain monoamines) } \\
\cline { 2 - 4 } & NE & DA & 5HT \\
\hline C & $0.668 \pm 0.016$ & $1.259 \pm 0.0294$ & $0.530 \pm 0.012$ \\
\hline Ca-F & $0.507 \pm 0.011 \mathrm{~b}$ & $1.073 \pm 0.025 \mathrm{~b}$ & $0.496 \pm 0.009 \mathrm{ab}$ \\
\hline G & $0.822 \pm 0.019 \mathrm{ab}$ & $1.291 \pm 0.29 \mathrm{~b}$ & $0.575 \pm 0.015 \mathrm{~b}$ \\
\hline MTX & $0.571 \pm 0.017 \mathrm{a}$ & $0.732 \pm 0.074 \mathrm{a}$ & $0.295 \pm 0.007 \mathrm{a}$ \\
\hline MTX + Ca-F & $0.543 \pm 0.013 \mathrm{~b}$ & $1.101 \pm 0.025 \mathrm{~b}$ & $0.441 \pm 0.010 \mathrm{~b}$ \\
\hline MTX +G & $0.662 \pm 0.015 \mathrm{~b}$ & $1.037 \pm 0.029 \mathrm{~b}$ & $0.472 \pm 0.014 \mathrm{~b}$ \\
\hline MTX + Ca-F +G & $0.681 \pm 0.016 \mathrm{~b}$ & $1.231 \pm 0.031 \mathrm{~b}$ & $0.503 \pm 0.015 \mathrm{~b}$ \\
\hline
\end{tabular}

- a significant from control group with one way ANOVA at $\mathrm{P}<0.05$.

- $\quad \mathrm{b}$ significant from $\mathrm{M}$ group with one way ANOVA at $\mathrm{P}<0.05$.

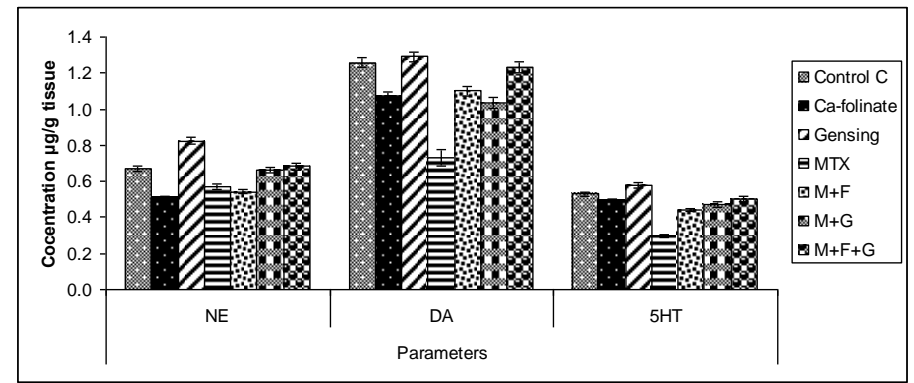

Figure (2): Effect of Ca-folinate, Ginseng and their combined treatments on monoamines levels in brain of rats treated with Methotrexate (MTX).

There were a decrease in NE, DA and 5HT in groups treated with MTX ( $\mathrm{p}<0.05)$ in comparing with control. While there were an increase in NE, DA and 5HT in groups treated in groups treated with $\mathrm{Ca}-\mathrm{F}+$ MTX, Gn+MTX and with Ca-F +MTX +Gn in comparing with MTX. Table (2) and fig (2).

Table (3): Effect of Ca-folinate, ginseng and their combined treatments on serum AST, ALT and $\gamma$ GT levels $(\mathrm{U} / \mathrm{ml})$ in rats treated with Methotrexate (MTX).

\begin{tabular}{|l|l|l|l|}
\hline \multirow{2}{*}{ Groups } & \multicolumn{3}{|l|}{ Parameters (Serum liver function) } \\
\cline { 2 - 4 } & ALT U/Ml & AST U/mL & $\square$ GT U/m*I \\
\hline C & $26.28 \pm 0.497$ & $73.63 \pm 1.734$ & $21.03 \pm 0.494$ \\
\hline Ca-F & $27.87 \pm 0.662$ & $69.67 \pm 1.64$ & $21.34 \pm 0.476$ \\
\hline G & $25.3 \pm 0.596$ & $64.8 \pm 1.461$ & $28.67 \pm 0.677$ \\
\hline MTX & $94.8 \pm 2.155 \mathrm{a}$ & $165.58 \pm 3.743 \mathrm{a}$ & $64.97 \pm 1.484 \mathrm{a}$ \\
\hline MTX+Ca-F & $45.51 \pm 1.033 \mathrm{ab}$ & $116.39 \pm 2.725 \mathrm{ab}$ & $57.01 \pm 1.275 \mathrm{ab}$ \\
\hline MTX+G & $54.87 \pm 1.249 \mathrm{ab}$ & $102.16 \pm 2.357 \mathrm{ab}$ & $49.63 \pm 1.168 \mathrm{ab}$ \\
\hline MTX + Ca-F +G & $52.06 \pm 1.233 \mathrm{ab}$ & $84.53 \pm 1.986 \mathrm{ab}$ & $37.4 \pm 0.854 \mathrm{ab}$ \\
\hline
\end{tabular}

- a significant from control group with one way ANOVA at $\mathrm{P}<0.05$.

- $\quad$ b significant from $\mathrm{M}$ group with one way ANOVA at $\mathrm{P}<0.05$.

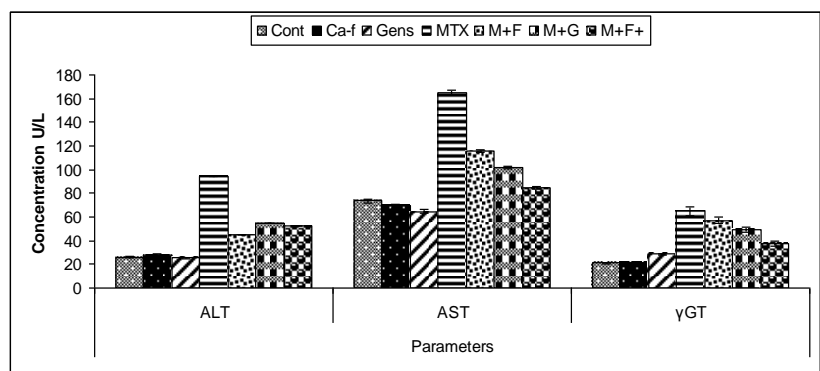

Figure (3): Effect of Ca-folinate, ginseng and their combined treatments on serum AST, ALT and $\gamma$ GT levels $(\mathrm{U} / \mathrm{ml})$ in rats treated with Methotrexate (MTX). 
Treatment rats with MTX showing increase in ALT, AST and $\gamma$-GT $(\mathrm{p}<0.05)$ comparing with control. In contrary there was decrease in ALT ,AST and $\gamma$-GT in groups treated with Ca-folinate+ MTX, Gn +MTX and $\mathrm{Ca}-\mathrm{F}+\mathrm{Gn}+\mathrm{MTX}$ in comparing with MTX. . Table (3) and fig (3).

Table (4): Effect of Ca-folinate, Ginseng and their combined treatments on MDA (nmol/g tissue), GSH $\mu \mathrm{mol} / \mathrm{g}$ tissue, GSSG $\mu \mathrm{mol} / \mathrm{g}$ tissue and NO ( $\mu \mathrm{mol} / \mathrm{g}$ tissue) in rats treated with Methotrexate (MTX).

\begin{tabular}{|l|l|l|l|l|}
\hline \multirow{2}{*}{ Groups } & \multicolumn{4}{l}{ Parameters (Liver oxidative stress marker) } \\
\cline { 2 - 5 } & MDA nmol / g Liver & GSH $\boldsymbol{\mu m o l} / \mathbf{g}$ Liver & GSSG $\boldsymbol{\mu m o l} / \mathbf{g}$ Liver & NO $\boldsymbol{\mu m o l} / \mathbf{g}$ Liver \\
\hline C & $6.254 \pm 0.143$ & $55.654 \pm 1.302$ & $12.054 \pm 0.282$ & $0.354 \pm 0.008$ \\
\hline Ca-F & $6.187 \pm 0.141$ & $53.369 \pm 1.251$ & $11.269 \pm 0.264$ & $0.378 \pm 0.009$ \\
\hline G & $6.987 \pm 0.157$ & $56.547 \pm 1.334$ & $12.258 \pm 0.289$ & $0.348 \pm 0.008$ \\
\hline MTX & $13.658 \pm 0.319 \mathrm{a}$ & $22.984 \pm 0.519 \mathrm{a}$ & $17.369 \pm 0.392 \mathrm{a}$ & $0.984 \pm 0.022 \mathrm{a}$ \\
\hline MTX + Ca-F & $9.587 \pm 0.224 \mathrm{ab}$ & $32.694 \pm 0.756 \mathrm{ab}$ & $14.684 \pm 0.34 \mathrm{ab}$ & $0.654 \pm 0.015 \mathrm{ab}$ \\
\hline MTX +G & $7.329 \pm 0.173 \mathrm{ab}$ & $37.152 \pm 0.852 \mathrm{ab}$ & $13.725 \pm 0.315 \mathrm{ab}$ & $0.601 \pm 0.014 \mathrm{ab}$ \\
\hline MTX + Ca-F +G & $6.984 \pm 0.156 \mathrm{~b}$ & $38.215 \pm 0.898 \mathrm{ab}$ & $12.884 \pm 0.303 \mathrm{ab}$ & $0.418 \pm 0.01 \mathrm{ab}$ \\
\hline
\end{tabular}

- a significant from control group with one way ANOVA at $\mathrm{P}<0.05$.

- $\quad \mathrm{b}$ significant from $\mathrm{M}$ group with one way ANOVA at $\mathrm{P}<0.05$.

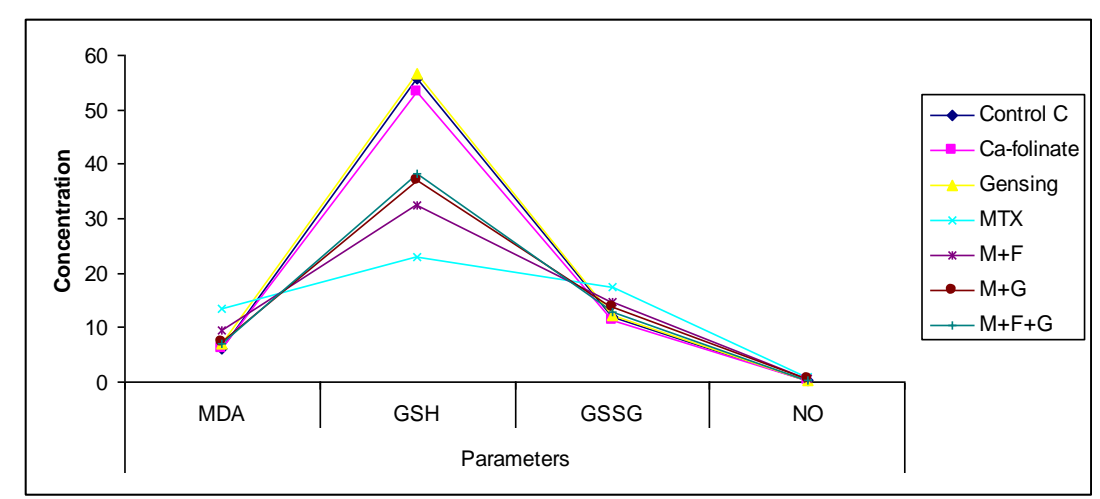

Figure (4): Effect of Ca-folinate, Ginseng and their combined treatments on MDA (nmol/g tissue), GSH $\mu \mathrm{mol} / \mathrm{g}$ tissue, GSSG $\mu \mathrm{mol} / \mathrm{g}$ tissue and NO ( $\mu \mathrm{mol} / \mathrm{g}$ tissue) in rats treated with Methotrexate (MTX).

There were an increase in MDA, GSH and GSSG in groups treated with MTX ( $\mathrm{p}<0.05)$ in comparing with control. While there was a decrease in NO in the same group treated with MTX and comparing with control. Also, there were a decrease in MDA, GSSG and NO in groups treated with Ca-F + MTX, G +MTX and $\mathrm{Ca}-\mathrm{F}+\mathrm{G}+\mathrm{MTX}$ in comparing with MTX while there was an increase in GSH in the same groups comparing with MTX. Table (4) and fig (4).

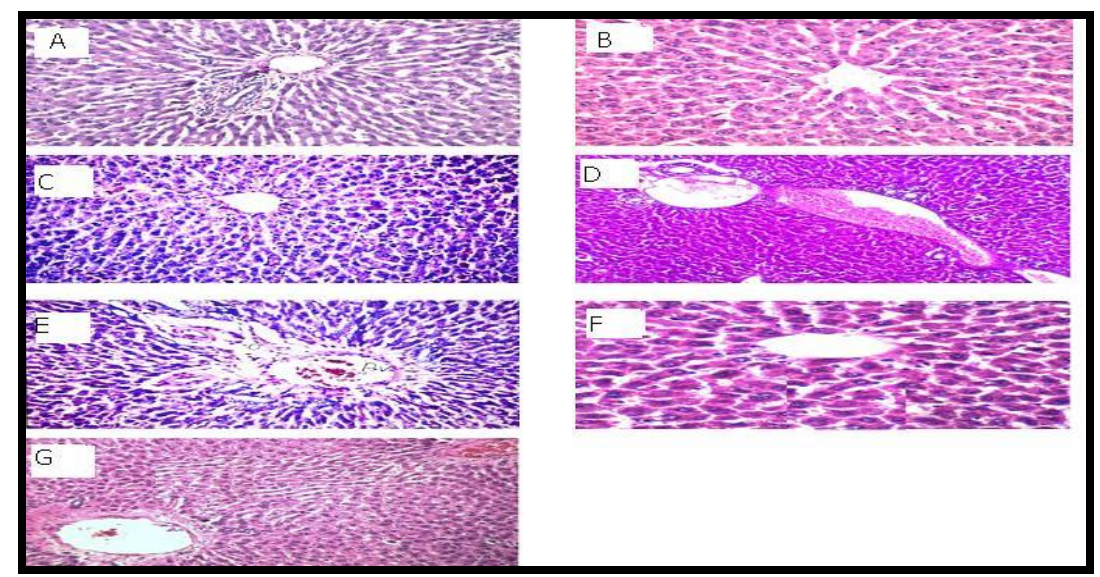

Figure 5: Histological examination of liver tissue

Figure 5 (A, B and C) for control, Ca-F and G groups respectively, didn't show any histopathological alteration in the central vein and surrounding hepatocytes in the hepatic parenchyma. Figure 5 (D) for MTX group showed dilatation in the central and portal veins associated with inflammatory cells infiltration and congestion in the portal area. Figure $5(\mathrm{E}, \mathrm{F}$ and $\mathrm{G})$ for MTX+Ca-F, MTX+G and MTX+Ca-F+G respectively, Showed ameliorative effect in liver tissue and few inflammatory cells infiltration in the portal area surrounding the bile ducts. 


\section{Discussion}

MTX is widely used as a cytotoxic chemotherapeutic agent in the treatment of various malignancies as well as various inflammatory diseases (Uzar, et al., 2006). The efficacy of this agent is often limited by its toxicity which causes severe side effects affecting the hematopoietic system and hepatocytes (Weinblatt and Fraser, 1989). Neurotoxicity of MTX was partly due to its direct toxic action by increasing reactive oxygen species production; MTX causes oxidative stress by reducing the activities of superoxide dismutase, catalase and glutathione reductase (Coleshowers et al., 2010). Gressier et al. (1994) demonstrated that MTX increases the amount of hydrogen peroxide and other free radicals which may lead to toxicity thus accelerating the rate of cellular damage. Our work highlights the importance of ginseng and ca-folinate in combination with chemotherapy aiding in reducing the MTX induced side effects. The results showed an increase in Aspartate and glutamate and decreasing in glycine and GABA after treatment with MTX these results may be due to oxidative stress which leads to change in amino acids in brain tissues. Also treatment with Ca-folinate and ginseng causing decrease in Aspartate and glutamate and increasing in glycine and GABA this is due improve in rats behavior and amino acids and decrease neurotoxicity of MTX. This results agree with Leskiewicz et al. (2008); Mauricio et al. (2014) whom decided that oxidative stresses lead to imbalance and disturbance between excitatory and inhibitory amino acids. Hence, the Neuroprotective effects of these drugs were mediated by modulation of target in GABA/GLYcinergic and glutamatergic pathway.

Proposed neurotoxicity by methotrexate is due to interference in supply of neurotransmitters. Our study has confirmed with Netter et al. (1991) reported that, the involvement of neurotransmitters in methotrexate induced learning and memory deficits. In which the level of NE, DA and 5HT were significantly decreased $(\mathrm{P}<0.05)$. Thus our present study claims that methotrexate induced neurotoxicity is due to impaired synthesis of amines, rather than cytotoxic effect. Millot et al., 1995 and Netter et al. (1991) supported this view, claiming that altered biopterine metabolism is blocking the synthesis of these amines in brain. The treatment with MTX showed decrease in NE, DA and 5HT and there was increase in NE, DA and 5HT after treatment with Cafolinate a ginseng and their combination this results agree with Bottiglieri et al., 2000 who decided that Altered monoamine neurotransmitter metabolism has been identified in psychiatric patients with folate deficiency , Also, low levels of serotonin metabolites were observed in the CSF of patients suffering from folate-responsive neuropsychiatric disease (Botez et al., 1982). The 5-HIAA/5-HT ratio is considered a sensitive index of utilization of 5-HT (Shannon et al., 1986).

The results of the studies indicate that MTX causes oxidative tissue damage by increasing lipid peroxidation in the liver tissue and decreasing the level of antioxidant enzymes. These lead to increasing AST, ALT and GGT values, biochemical indicators of liver damage, and histopathological findings supported this conclusion. In our study, after MTX injection, AST, ALT and GGT levels, known indicators of hepatic damage, had increased compared with the control group. It is known that in the use of drugs causing liver toxicity transaminase levels increase in the plasma depending upon the degree of hepatic damage. Kuvandik et al. (2008) reported that the levels of AST and ALT in plasma serum have increased significantly in acetaminophen hepatotoxicity; and Uzar et al. (2006) reported that MTX also increased ALT levels. In our study; the level of AST and ALT in the group supplied with ginseng and Ca-F was statistically lower than in those animals given MTX alone. Sugiura et al. (2006) reported that flavonoides may prevent increases of serum aminotransferase increase in the early periods of liver damage in hyperglycemic patients.

The mechanisms involved in MTX-induced hepatic damage were investigated and our results showed that MTX induced oxidative stress, evident by decreased GSH level and increased lipid peroxidation product, MDA, GSSG and NO which was in concurrence with previous studies (Morsy et al ., 2013). In the current study, it was found that ginseng improved antioxidants' levels and decreased MDA, GSSG, and NO levels in the treated group when compared to control group. In agreement, Liu et al. (2003) found that ginseng extracts scavenge oxidative species; also, Surh et al. (2001) indicated that ginseng extracts attenuate lipid peroxidation. Ameliorative effect of ginseng may be due to saponins which play a major role in antioxidant activities. In addition, ginsenoides which are important components heavily present in ginseng production of powerful antioxidant activities other than radical scavenging activities by stimulating gene expression of antioxidant enzymes and enhancing their activities. These results were in agreement with Kim et al. (2003) who reported that, ginseng saponins have been proposed as possible candidates in the research of therapeutic modulation of stress related disorders, for their inhibitory effect on the level of stress.

\section{References}

[1]. Arafa, N.M.S. Salem, S.M. and Ahmed-Farid, O.A. (2010). Influence of Echinacea extract pre- or postnatal supplementation on immune and oxidative status of growing rabbits Italian J of Animal Sci., 9: 338-43.

[2]. Banchroft, J.D. Stevens, A and Turner, D.R. (1996). Theory and practice of histological techniques. fourth ed. churchil livingstone ,new york, london, san francisco, toky

[3]. Botez, M.I. Young, S.N. Bachevalier, J and Gauthier, S. (1982). Effect of folic acid and vitamin B12 deficiencies on 5hydroxyindoleacetic acid in human cerebrospinal fluid. Ann Neurol 12:479 -484. 
[4]. Bottiglieri, T, Laundy, M, Crellin, R, Toone, B.K, Carney, M.W, and Reynolds, E.H. (2000). Homocysteine, folate, methylation, and monoamine metabolism in depression. J Neurol Neurosurg Psychiatry 69:228 -232.

[5]. Coleshowers, C.L. Oguntibeju, O.O. Ukpong, M and Truter, J.E. (2010). Effects of methotrexate on antioxidant enzyme status in a rodent model. Medical Technology SA 24:5-9.

[6]. Gressier, B, Lebegue S, Brunet C, LuyckxM, Dine, T. Cazin, M and Cazin, J.C. (1994). Pro-oxidant properties of methotrexate: evaluation and prevention by an antioxidant drug. Pharmazie 49:679-681.

[7]. Heinrikson, R.L and Meredith, S.C. (1984). Amino acid analysis by RP-HPLC: precolumn Derivatization with phenylisothiocyanate. Anal. Biochem, 136: 65-74.

[8]. Jayatilleke, E. and Shaw, S. (1993). A high performance liquid chromatographic assay for reduced and oxidized glutathione in biological samples. Anal. Biochem., 214(2): 452-457.

[9]. Karalas, F. Karatepe, M and Baysar, A. (2002). Determination of free malondialdehyde in human serum by high performance liquid chromatography. Anal. Biochem., 311:76-79.

[10]. Karatepe, M. (2004). Simulatenous determination of ascorbic acid and free malondialdehyde in human serum by HPLC-UV. Chromatographic Line., 12:362-365.

[11]. Kelly, G.S. (1998). Folates: Supplemental Forms and Therapeutic Applications. Alt Med Rev. 3(3): p. 208-220.

[12]. Kim, D.H, Moon, Y.S, Lee, T.H, Jung, J.S, Suth, H.W and Song, D.K. (2003). The inhibitory effect of ginseng saponins on the stress-induced plasma interleukin-6 level in mice. Neutrosci. Lett., 1: 13-16.

[13]. Kuvandik, G, Duru M, Nacar A, Yonden Z, Helvaci R, Koc A, Kozlu, T. Kaya, H, and Sogüt S. (2008). Effects of erdosteine on acetaminopheninduced hepatotoxicity in rats. Toxicol. Pathol. 36:714-719.

[14]. Leskiewicz, M, Jantas D, Budziszewska, B and Lason, W. (2008). Excitatory neurosteroids attenuate apoptotic and excitotoxic cell death in primary cortical neurons. J Physiol Pharmacol 59: 457-475.

[15]. Li, MC; Hertz, R and Spencer, DB. (1956). Effect of methotrexate upon choriocarcinoma. Proc Soc Exp Biol Med;93:361-366.

[16]. Liu, Z.Q Luo, X.Y, Liu, G.Z, Chen, Y.P, Wang, Z.C and Sun Y.X. (2003). In vitro study of the relationship between the structure of ginsen,oside and its antioxidative or prooxidative activity in free radical induced hemolysis of human erythrocytes. J. Agric. Food Chem., 51: 2555-2558

[17]. Mauricio, O. Lydia, N. Javier, J.Y and Juan, D.N. (2014). GABAergic neurotransmission and new strategies of neuromodulation to compensate synaptic dysfunction in early stages of Alzheimer's disease. Frontiers in Cellular Neuroscience. 8:167-1.

[18]. Millot, D. Mazingue, F. Mechinaud, P, Ingrand, F and Guilhot, F. (1995). Changes of cerebral biopterin and biogenic amine metabolism in leukemic children receiving $5 \mathrm{~g} / \mathrm{m} 2$ intravenous methotrexate. Pediatr Res; $151-154$.

[19]. Netter, J.C. Dhondt, F. Ranee, F and Petrus, M. (1991). Early neurotoxicity of high dose of methotrexate and tetrahydrobiopterin deficiency. Arch Fr Pediatr; 48: 719-722.

[20]. Olfert, E. Cross, B and McWilliam, A. (1993). Canadian Council on Animal Care, Guide to the care and use of experimental animals.

[21]. Pagel, P.; Blome, J and Wolf, H.U. (2000). High-performance liquid chromatographic separation and measurement of various biogenic compounds possibly involved in the pathomechanism of Parkinson's disease Journal of Chromatography B, 746: 297-304.

[22]. Papadoyannis, L.N. Samanidou, V.F. and Nitsos, C.C. (1999). Simultaneous determination of nitrite and nitrate in drinking water and human serum by high performance anion-exchange chromatography and UV detection. J. Liq. Chrom. Rel. Technol., 22(13): $2023-2041$

[23]. Saito, H. Tsuchiya, M. Naka, S and Takagi, K. (1977). Effect of Panax Ginseng root on conditioned avoidance response in rats. Jpn J Pharmacol 27: 509-516.

[24]. Shannon, N.J. Gunnet J.W and Moore K.E. (1986). A comparison of biochemical indices of 5-hydroxytryptaminergic neuronal activity following electrical stimulation of the dorsal raphe nucleus. J Neurochem; 47:958-965.

[25]. Sugiura, M. Ohshima, M. Ogawa, K and Yano, M. (2006). Chronic administration of Satsuma mandarin fruit improves oxidative stress in streptozotocininduced diabetic rat liver. Biological and Pharmaceutical Bulletin, 29, 588-591.

[26]. Surh, Y.J. Na H.K. Lee J.Y. and Keum, Y.S (2001). Molecular mechanisms underlying anti-tumor promoting activities of heatprocessed Panax ginseng C.A Meyer. J. Korean Med. Sci., 16: S38-S41.

[27]. Uzar, E. Sahin O. Koyuncuoglu H.R, Uz E. Bas O and Kilbas, S. (2006). The activity of adenosine deaminase and the level of nitric oxide in spinal cord of methotrexate administered rats: Protective effect of caffeic acid phenethyl ester. Toxicology; 218(23):125-33.

[28]. Weinblatt M.E and Fraser P. (1989). Elevated mean corpuscular volume as a predictor of hematologic toxicity due to methotrexate therapy. Arthritis Rheum; 32(12):1592-6.

[29]. Xun, X.H. and Zhou, J.L. (2003). Progress of research on ginsenosides. China Journal of Modern Medicine 13: 43-44. 